\title{
Re-orientation of Russia to the Asian markets as a main direction of its foreign trade policy
}

\author{
Olga Solodukhina ${ }^{1}$, Tatyana Bukreeva, ${ }^{2,}$, Irina Minakova $^{1}$, and Artyom Golovin ${ }^{1}$ \\ ${ }^{1}$ Southwest State University, Faculty of Public Administration and International Relations, \\ Department of Customs and World Economy, ulitsa Chelyuskintsev 19, 305004 Kursk, Russia \\ ${ }^{2}$ Southwest State University, Faculty of Public Administration and International Relations, \\ Department of International Relations and Public Administration, ulitsa Chelyuskintsev 19, 305004 \\ Kursk, Russia
}

\begin{abstract}
.
Research background: The authors on a systematic basis have investigated the features of trade relations between Russia and neighboring Asian states. It was published several articles on this issue in Russia and abroad, including publications in Scopus and Web of Science indexed journals.

Purpose of the article: The aim of the research is to analyze the current situation and prospects for the development of mutual trade cooperation between Russia and neighboring Asian states (Kazakhstan, Mongolia, China, Kyrgyzstan, Tajikistan, Uzbekistan and Turkmenistan).

Methods: The research is based on the methodology of general system theory. The present research was accomplished using the following methods for studying complex social objects: synthesis, comparison, system analysis, analogy, construction of scientifically based hypotheses, etc. The theoretical basis for the study was the works of M.O. Slobodchikoff, M.E. Aleprete [1], P. Bargues-Pedreny [2], R. Mac Ginty [3], and J. L. Austin [4].

Findings \& Value added: The authors have investigated mutual trade cooperation between Russia and neighboring Asian states (Kazakhstan, Mongolia, China, Kyrgyzstan, Tajikistan, Uzbekistan and Turkmenistan). The study has showed that the major problem of Russia's trade with neighboring Asian states is based on resource-oriented export. Russia's key task at Central Asian market is to expand the share of non- resource-based sectors. A variety of export categories will make the Russian economy more resilient to global fluctuations and crises. At the same time, it is necessary to develop trade and economic cooperation with India, Indonesia and Brazil, as well as to form a coalition of non-aligned countries and African countries in order to deter China and the USA.
\end{abstract}

Keywords: 'Asianization of the world'; trade and economic cooperation; Pivot to the East

JEL Classification: $F 13 ; F 14$

*Corresponding author: tnbinchina@yandex.ru 


\section{Introduction}

All forecasts made by reputable agencies indicate deterioration in the positions of European countries in the world ranking. In this regard, John Hawkesworth, a chief economist at PwC and one of the authors of the report, notes: 'Europe must make efforts to improve its results; otherwise it will be left behind as a result of the ongoing changes in the balance of power in the global economy. These changes return us to a situation when the leading role in the world economy belonged to the Asian region. This situation was last seen before the industrial revolution' [5].

After studying the countries' exchange rates in terms of PPP and nominal GDP, analysts of Standard Chartered Bank have arranged their results in a table (see table 1) [5]. According to Standard Chartered (a British multinational banking and financial services company), it is expected a rise of the Asian economies in the next decade, they will be in the world's top 10 largest economies. Their share will reach $35 \%$ by 2030 , that is in line with the indicators of Europe and the US put together. According to the current projections, the world population will reach 8.5 billion by 2030; about 5 billion of people will live in Asia. It is projected that China and India will overtake the US, and become the world's largest and second largest economies respectively. The US will drop to third place.

Table 1. The Top 10 Economies in the World by 2030.

\begin{tabular}{|c|c|c|}
\hline Ranking & Country & $\begin{array}{c}\text { GDP forecast (2030, PPP), } \\
\text { USD, billion }\end{array}$ \\
\hline 1 & China & 64,2 \\
\hline 2 & India & 46,3 \\
\hline 3 & The United States & 31,0 \\
\hline 4 & Indonesia & 10,1 \\
\hline 5 & Turkey & 9,1 \\
\hline 6 & Brazil & 8,6 \\
\hline 7 & Egypt & 8,2 \\
\hline 8 & Russia & 7,9 \\
\hline 9 & Japan & 7,2 \\
\hline 10 & Germany & 6,9 \\
\hline
\end{tabular}

In this situation, the adoption by the Russian government of Pivot to the East program is a fully justified strategic decision aimed at diversifying foreign markets. The reorientation of the foreign trade relations of Russia is a need caused by the Western sanctions against Russia introduced in 2014.

From the beginning, the implementation of this program was not easy: during 20122014, the share of Eastern markets in Russia's foreign trade turnover remained extremely insignificant [6]. In this regard, the program required the mobilization of significant administrative, financial, time, personnel and other resources.

The aim of the study is to analyze the current situation and prospects for the development of mutual trade cooperation between Russia and neighboring Asian states (Kazakhstan, Mongolia, China, Kyrgyzstan, Tajikistan, Uzbekistan and Turkmenistan). 
The study is based on the methodology of general systems theory. During the research process the following methods for studying complex social objects were employed: synthesis, comparison, system analysis, analogy, building science-based hypotheses, etc.

\section{Methodology}

The research is based on the methodology of general system theory. The present research was accomplished using the following methods for studying complex social objects: synthesis, comparison, system analysis, analogy, construction of scientifically based hypotheses, etc. The theoretical basis for the study was the works of M.O. Slobodchikoff, M.E. Aleprete [1], P. Bargues-Pedreny [2], R. Mac Ginty [3], and J. L. Austin [4].

\section{Research results}

Russia's neighbouring states in the East, Kazakhstan, Mongolia, China, Kyrgyzstan, Tajikistan, Uzbekistan and Turkmenistan, are its strategically important trade and economic partners.

\subsection{Kazakhstan}

Kazakhstan has a lengthy mutual border with Russia; it has a positive impact on the economies of both countries. Russia-Kazakhstan trade is stable and steady. Many bilateral cooperation agreements and joint development agreements have been signed. Active investment cooperation is being implemented.

Kazakhstan's GDP is growing due to the active development of the extractive industries. The volume of foreign trade is also increasing. In 2018, the growth in foreign trade was $20.4 \%$. At the same time, exports increased by $26.1 \%$ from USD 48.3 billion to USD 61.0 billion, and imports - by $11.0 \%$ from USD 29.3 billion to USD 32.5 billion [7]. [8].

The Russia's share in the structure of Kazakhstan's imports is $38.1 \%$, China's $-16.5 \%$

Russia-Kazakhstan trade has two main problems: the obvious import-export asymmetry (exports to Kazakhstan exceed the volume of imports from it by 2.4 times) and the destabilization of trade relations in the fuel and raw material sector. This problem can be solved by diversifying the commodity categories exported to Kazakhstan and reducing the total share of products of fuel and energy complex in trade between two countries.

\subsection{Mongolia}

Mongolia occupies a unique geographic position: the country is literally 'sandwiched' between Russia from the north and China from the south. In this regard, it would be logical to assume a strong competition from China in the Mongolian market. However, the study shows that the main problem of Russia-Mongolia trade cooperation is not in such a strong competitor as the Middle Kingdom, but in underdevelopment of trade and political relations between Russia and Mongolia [9].

In the early $90 \mathrm{~s}$, Mongolia declared the rejection of a single-vector foreign policy oriented towards Moscow and began to implement a multi-vector strategy based on building balanced relations with its geographic neighbours Russia and China, at the same time developing cooperation with other countries: the US, Japan and Germany. These countries were supposed to balance the Russian and Chinese influence on Mongolia. 
Another important principle of Mongolia's foreign policy is based on the refusal to join any military-political blocs like the WPO or NATO. It is no coincidence that the constitution of Mongolia does not allow the deployment of foreign military bases on its territory. These principals of foreign policy are fundamental for building regional relations with the rest of the world.

Since the 2000s, the SCO has become the most important institutional structure formed as a result of the integration processes in Central Asia; the cooperation with this organization is one of the directions of Mongolia's multi-vector policy at the regional level [10].

In 2018, the aggregate foreign trade turnover of Mongolia amounted to USD 12.9 million. The share of Russia in Mongolia's foreign trade does not exceed 13\% [11]. It should be noted that over the same period Mongolia's import to Russia was USD 43.26 million. Given that Russia's export to Mongolia in the same period reached USD 1,610 million. The import-export asymmetry seems to be catastrophic: export exceeds import by more than 37 times [11]. At the same time, the studies show that Mongolia's export is mainly China-oriented.

To solve this problem, it is necessary to update the existing and develop new programs for the promotion of Russia-Mongolia cooperation.

\subsection{China}

China is an industrial giant; currently it sees Russia as a raw material base. The indicators of Russia-China bilateral trade have proved this statement.

In January-June 2018, China's foreign trade turnover amounted to almost USD 2.206 billion; Russia's share was only $2.2 \%$. Russia ranked 11 th in the list of China's major trade partners, even behind Japan, Vietnam, Malaysia and the United States. In 2018, the United States accounted for $13.68 \%$ of China's foreign trade turnover (Table 2) [12].

Table 2. China's trade turnover with major partners in January-June 2018.

\begin{tabular}{|c|c|c|c|c|c|c|}
\hline \multirow{2}{*}{ Countries } & \multicolumn{3}{|c|}{ Value (million, USD) } & \multicolumn{3}{c|}{ Increase (\%) } \\
\cline { 2 - 7 } & $\begin{array}{c}\text { Trade } \\
\text { turnover }\end{array}$ & Export & Import & $\begin{array}{c}\text { Trade } \\
\text { turnover }\end{array}$ & Export & Import \\
\hline Total & 2205845,2 & 1172746,4 & 1033098,7 & 16,0 & 12,8 & 19,9 \\
\hline $\begin{array}{c}\text { the United } \\
\text { States }\end{array}$ & 301801,6 & 217778,8 & 130794,1 & 13,1 & 13,6 & 11,8 \\
\hline Japan & 157502,0 & 70396,7 & 87105,3 & 10,7 & 8,0 & 12,9 \\
\hline $\begin{array}{c}\text { Republic of } \\
\text { Korea }\end{array}$ & 152317,2 & 53872,3 & 98444,9 & 16,9 & 9,0 & 21,8 \\
\hline Hong Kong & 141377,0 & 137745,6 & 3631,5 & 13,5 & 13,7 & 8,3 \\
\hline Taiwan & 107823,3 & 23212,2 & 84611,1 & 22,0 & 14,4 & 24,2 \\
\hline Germany & 87946,2 & 36559,4 & 51386,8 & 12,8 & 10,0 & 14,9 \\
\hline Australia & 74117,4 & 21702,4 & 52415,0 & 11,5 & 17,3 & 9,3 \\
\hline Vietnam & 66042,3 & 39138,0 & 26904,3 & 28,8 & 23,5 & 37,4 \\
\hline Malaysia & 51948,2 & 21697,6 & 30250,6 & 15,1 & 10,6 & 18,6 \\
\hline
\end{tabular}




\begin{tabular}{|c|c|c|c|c|c|c|}
\hline Brazil & 51902,5 & 17209,9 & 34692,6 & 24,3 & 34,0 & 20,0 \\
\hline Russia & 49146,9 & 22521,2 & 26625,7 & 24,8 & 17,7 & 31,6 \\
\hline India & 46919,7 & 37427,6 & 9492,1 & 15,1 & 15,0 & 15,5 \\
\hline Thailand & 43035,0 & 21162,8 & 21873,0 & 14,1 & 16,6 & 12,0 \\
\hline Singapore & 41504,6 & 24369,0 & 17135,6 & 12,4 & 16,1 & 7,4 \\
\hline $\begin{array}{c}\text { the } \\
\text { Netherlands }\end{array}$ & 40090,6 & 33780,3 & 6310,3 & 14,0 & 14,2 & 13,1 \\
\hline Indonesia & 37438,2 & 20017,0 & 17421,3 & 27,7 & 23,3 & 33,2 \\
\hline The UK & 36214,0 & 25276,9 & 10937,1 & $-1,9$ & $-3,1$ & 0,8 \\
\hline Canada & 29085,3 & 15597,9 & 13487,5 & 18,8 & 10,8 & 29,7 \\
\hline France & 28956,2 & 14781,4 & 14174,7 & 16,5 & 15,0 & 18,1 \\
\hline Italy & 26428,2 & 16023,6 & 10404,6 & 13,2 & 13,8 & 12,2 \\
\hline
\end{tabular}

A similar situation was observed in 2015-2017: the US was China's main trade partners (trade turnover: in 2015 - USD 558385.06 million, in 2017 - USD 583701.40 million), Japan (trade turnover: in 2015 - USD 278,664.11 million, in 2017 - USD 302,986.64 million), the Republic of Korea (trade turnover: in 2015 - USD 275,899.07 million, in 2017 - USD 280,281.85 million). While the trade turnover with Russia in 2015 was USD 68,065.15 million, and in 2017 - USD 84,071.09 million [13].

Russia exports to China mineral fuels, oil, petroleum products, timber, agricultural products, non-ferrous metals, fish, ores, slags and ash, paper pulp, cellulose and chemical products. Fuel, oil and oil products $(69.82 \%)$, timber $(8.82 \%)$ are the main export products. The share of other products does not exceed $2.2-5.5 \%$ in the total volume of Russian export to China [14]. This situation raises serious strategic concerns.

China traditionally implements a policy of active promotion of Chinese goods in foreign markets [15]. Such competitive advantages of the Chinese economy as reasonable prices, WTO membership facilitate this policy $[16,17]$.

In September 2013, China announced the developing of the New Silk Road project, which combines the strategies of the Silk Road Economic Belt and the 21st Century Maritime Silk Road. The first one aims to connect China with Europe through Central Asian countries and Russia. The second strategy involves the intensification of cooperation with the countries of East Africa, West, South and South-East Asia, and Europe.

In general, the Economic Belt is a land route for Chinese products, currently mainly transported by sea. In this regard this initiative will help to strengthen China's position in the region. But it can create the situation of crowding out Russian goods by cheaper Chinese counterparts. On the other hand, as a result of the transition to settlements in national currencies, a rise of the Chinese currency (yuan) is inevitable: the Central Asian countries are export-oriented to the Russian market, and they mainly import Chinese goods.

For domestic producers, Chinese expansion poses a threat in mechanical engineering, agriculture, and textile industry. It should be noted that at the same time, China's investment activity is aimed at a very limited number of industries. They are natural resources extraction and food production; it is confirmed by the ongoing contracts for the Power of Siberia and the Western Route. The existing infrastructure projects are designed 
to ensure transporting Chinese products to Europe and resources for the needs of the Chinese economy [18].

At the same time, China demonstrates ineffective economic management. Dirty industries, predatory devastation of forests, and irrational land use are the direct evidence of this. This policy damages the environment of Siberia and the Far East. The operations of Chinese capital set a pragmatic goal to make a profit.

However, the noted circumstances do not mean a total absence of areas of common interest. Nowadays, China is the main and most important partner of Russia in the international arena, which is not only because of the deterioration of Russia's relations with the West, but also due to the current international situation in general [19, 20, 21].

Russia needs a competent strategy, where China will retain the status of Russia's ally and partner, while Siberia and the Far East will be effectively developing territories free from Chinese influence.

\subsection{Kyrgyzstan}

In 2017, the foreign trade turnover of Kyrgyzstan amounted to almost USD 6.3 billion. The geographical structure of imports of Kyrgyzstan is dominated by China (33.4\%) and Russia (27\%) [22]. Russia imports to Kyrgyzstan fuel, plastic, pharmaceutical and ferrous metal products. Chinese export to Kyrgyzstan includes clothing, footwear and plastic. Expanding Russia's market share in this country is a doable task. However, the foreign trade turnover of Kyrgyzstan is rather small and even a share of $50 \%$ or more would not bring Russia tangible profit.

\subsection{Tajikistan}

In 2018, the volume of Tajikistan's foreign trade exceeded USD 4.2 billion [23]. Russia is Tajikistan's main trade partner with a turnover of USD 651.9 million. Kazakhstan is in 2nd place with a turnover of USD 553.3 million [23].

GDP growth in Tajikistan remains high, for 2017-2018 is more than 7\% annually [23]. Russian trade cooperation with Tajikistan is well developed, and against the background of the Tajikistan's economic growth, Russia opens up new opportunities to expand its share in this market.

\subsection{Uzbekistan}

In 2018, GDP growth in Uzbekistan was 5\% [24]. The foreign trade turnover increased by $17.6 \%$ [24]. Uzbekistan's key partners are China (19.8\% of foreign trade turnover) and Russia (17.8\% of foreign trade turnover). Kazakhstan is in 3rd place with a share of $9.1 \%$ [24].

A specific feature of Uzbekistan is its foreign policy: the government of the country has taken a course to converge with the CIS countries, which makes the development of this market more favorable and easy. In this regard, the most important task for Russia is to take priority positions in the Uzbekistan's market.

\subsection{Turkmenistan}

Turkmenistan ranks 4th in terms of natural gas reserves in the world and 10th in terms of its production. In 2018, the GDP of Turkmenistan amounted to USD 42.76 million with an annual growth of 5.5-7.5\%. However, the share of Russia in Turkmenistan's foreign trade 
does not exceed $9 \%$, while China accounts for $36 \%$, Iran $-19 \%$, Turkey $-13 \%$, and India $12 \%[25]$.

Russia needs to develop cooperation with Turkmenistan and strengthen its positions in the Turkmen market, competing with goods from India and Iran, since the quality of Russian products is comparable to the quality of goods produced in these countries.

\section{Discussion and Conclusion}

In 1990s, the decline of the era of Western dominance began. At that period of time, a term 'asianization of the world' entered the scientific circulation, and the centre of the world trade gradually began moving to APR. For the Russian economy, pivot to the East is a thoughtful, balanced and long overdue decision, and not a showcase or a temporary measure, as it might seem. Over the past 14 years, the Russian government has noted the need of reorientation towards Asian markets. Western sanctions became a catalyst, without being the determining reason for Russia's pivot to the East.

However, it should be noted that Russia's trade is more oriented to the markets of nonCIS countries. Kazakhstan is the only CIS country that has relatively significant volumes of export-import operations with Russia.

The study has shown that raw material-oriented export is the most important problem of Russia's trade with the neighbouring Asian states. This problem is not a new one, and it is common not only for the eastern markets, but also for Russia's foreign trade as a whole. The key task in the eastern markets is to expand the share of non-resource sectors. A wide range of export products will make the Russian economy more resilient to global fluctuations and crises.

At the same time, we should note that the export loss of USD 73.8 billion (the difference between export indicators in 2015 and 2018) will be hardly compensated by expanding only in the markets discussed above.

The pivot to the East was strategically and logically correct, but not an exhaustive solution. It is also necessary to develop trade and economic cooperation with India, Indonesia and Brazil, a coalition with these countries will make possible to contain China and the US.

Russia also should strengthen its positions on the African continent. It is noteworthy that certain measures in this direction are already being implemented, as evidenced by the Russia-Africa Summit and Economic Forum held in Sochi in October 2019. At the Summit, it was decided to ensure the increase in trading volume between Russia and the African countries. But it is necessary to diversify its nomenclature, primarily due to increasing the share of agricultural products in import and export operations. It is important actively promote the work of the existing bilateral Russian-African intergovernmental commissions and committees on trade, economic, scientific and technical cooperation. The strategic task is to create new mechanisms of partnership between Russia and Africa.

The research paper is written as part of the state grant for 2020 (№0851-2020-0034).

\section{References}

1. Slobodchikoff, M. O., Aleprete, M. E. (2020). The Impact of Russian-led Eurasian Integration on the International Relations of the Post-Soviet Space. Europe-Asia Studies, forthcoming article.

2. Bargues-Pedreny, P. (2019). From Critique to Affirmation in International Relations. Global Society, 33(1), 1-11. 
3. Mac Ginty, R. (2019). Circuits, the everyday and international relations: Connecting the home to the international and transnational. Cooperation and Conflict, 54(2), 234253.

4. Austin, J. L. (2019). A Parasitic Critique for International Relations. International Political Sociology, 13(2), 215-231.

5. Hawksworth, J., Chan, D. (2015, February). The World in 2050 Will the shift in global economic power continue? PricewaterhouseCoopers. Retrieved from: https://www.pwc.com/gx/en/issues/the-economy/assets/world-in-2050-summaryreport-february-2015.pdf

6. Ma, B. (2017). Russian 'Pivot to the East' Strategy: Opportunities and Challenges for Coupling with Chinese Transregional Projects. Comparative Politics Russia, 8(2), 8297.

7. Shibutov, M. M. (2016, November, 30). Analysis of the current state of KazakhRussian relations. Tsentr Sulakshina. Retrieved from: http://rusrand.ru/analytics/kazahstan-i-rossiya-itogi

8. Tugzhanov, E. (2019, April 11). Kazakhstan center of industry and export. Analysis of the state of foreign trade of Kazakhstan 2018. Forbes Kazakhstan. Retrieved from: https://forbes.kz/process/kazahstanskiy_tsentr_industrii_i_eksporta_analitika_i_gospod derjka_po_vsey_tsepochke_promyishlennosti

9. Sharladaeva I. A., Bazhenova V. S., Potaev, V. S. (2015). Problems of international interaction of border regions between Russia and Mongolia. Vestnik of Buryat State University, 2a, 216-221.

10. Minakova, I. V., Bukreeva, T. N., Parkhomchuk, M. A., Golovin, A. A. (2018). Modern Economic Development: Problems and Prospects. In K. S. Soliman (Ed.), Innovation Management and Education Excellence through Vision 2020: Proceedings of the 31st IBIMA Conference (pp. 2975-2981). Milan: IBIMA.

11. Trade turnover between Russia and Mongolia in 2018. (2019, February 9). Russian Foreign Trade. Retrieved from: https://russian-trade.com/reports-and-reviews/201902/torgovlya-mezhdu-rossiey-i-mongoliey-v-2018-g/

12. Data on China's trade with the largest foreign trade partners, the main items of Russian exports and imports, as well as key indicators of the economic development of the PRC. (2017). Russchinatrade. Retrieved from: https://russchinatrade.ru/assets/files/ru-ru-cn-coop/stat_2017.pdf

13. Economy and foreign trade of the PRC. (2016). China-Tomsk 2016. Retrieved from: $\mathrm{http}: / / \mathrm{china2016.tomsktpp.ru/экономика-и-внешняя-торговля-кнр/}$

14. Data on China's trade with major foreign trade partners, the main items of Russian exports and imports, as well as key indicators of China's economic development (quarterly). (2018). Russchinatrade. Retrieved from: http://www.russchinatrade.ru/assets/files/ru-ru-cn-coop/stat_2018.pdf

15. Yin, W. (2020). A comparison of the US and EU regulatory responses to China's state capitalism: implication, issue and direction. Asia-Europe Journal, forthcoming article.

16. Minakova, I. V., Bukreeva, T. N., Masalov, E. I., Galchenko, S. I., Kharlanova, V. N. (2019). Global management of modern world development: current situation and development prospects. In K. S. Soliman (Ed.), Vision 2020: Sustainable Economic Development and Application of Innovation Management: Proceedings of the 33nd IBIMA Conference (pp. 914-921). Granada: IBIMA.

17. Broz, J. L., Zhang, Z. W., Wang, G. Y. (2020). Explaining Foreign Support for China's Global Economic Leadership. International organization, 74(3), 417-452. 
18. Golovin, A.A. Dobrinova, T.V., Golovin, Al.A, Parkhomchuk, M.A, Vasileva, Z.A. (2019). Study of foreign trade policy of the developed and developing world economies. Proceedings of the 33 ${ }^{\text {nd }}$ IBIMA Conference: Vision 2020: Sustainable Economic Development and Application of Innovation Management (pp. 1574-1585). Granada: IBIMA.

19. Kashin, V. B., Piatachkova, A. S., Krasheninnikova, L. S. (2020). Chinese economic sanctions policy: theory and practice. Comparative Politics Russia, 11(2), 123-138.

20. Kwan, C. H. (2020). The China-US Trade War: Deep-Rooted Causes, Shifting Focus and Uncertain Prospects. Asian Economic Policy Review, 15(1), 55-72.

21. Swenson, D. L., Woo, W. T. (2019). The Politics and Economics of the US-China Trade War. Asian Economic Papers, 18(3), 1-28.

22. Foreign trade of the Kyrgyz Republic in 2017. National Statistical Committee of the Kyrgyz Republic. Retrieved from: http://www.stat.kg/media/publicationarchive/d3661938-32b8-40ba-abd9-e032f0014d2c.pdf

23. Trade between Tajikistan and the CIS countries increased by 17.8\%. (2018, September 21). EurAsia Daily. Retrieved from: https://eadaily.com/ru/news/2018/09/21/tovarooborot-tadzhikistana-so-stranami-sng-uvelichilsya-na-178

24. Uzbekistan's GDP grew by 5.1\% in 2018. (2019, January 23). Gazeta.uz. Retrieved from: https://www.gazeta.uz/ru/2019/01/23/gdp/

25. Sarybaeva, A. (2019, May 20). What is the economy of Turkmenistan? MMF. Retrieved from: https://moneymakerfactory.ru/biznes-idei/ekonomika-turkmenii/ 